\title{
Luis Buñuel: el fantasma de la libertad entre el instinto y la risa
}

$\frac{\text { Eduardo Peñuela Cañizal }}{\text { USP/UNIP }}$ 


\section{Resumo}

Os temas abordados por Buñuel nos são bem conhecidos, mas o que é importante em seus filmes é a maneira de apresentar esses temas através da mistura de elementos racionais e irracionais. Para o diretor espanhol o cinema é um instrumento de poesia e, nessa perspectiva, ele desenvolve modalidades de escrita destinadas a expressar todo tipo de significações libertárias. Neste artigo se aborda uma dessas maneiras de escrita cinematográfica.

Palavras-chave

Filmes de Buñuel, modalidades de escrita, significação libertária.

\section{Abstract}

Buñuel's themes are familiar to us, but what is important in his films is how he presents these themes as a mixture of the rational and the irrational. For the Spanish director film is an instrument of poetry and, in this sense, he develops writing modalities to express all kind of liberating significations. In the article the author explores one of these manners of cinematographic writing.

\section{Keywords}

Buñuel's films, writing modalities, liberating significations. 
"Pero la Ciencia no me interesa. Me parece presuntuosa, analítica y superficial. Ignora el sueño, el azar, la risa, el sentimiento y la contradicción, cosas todas que me son preciosas."

$\mathrm{E}$ 1 hecho de que el animal humano tardase siglos y siglos para conseguir inventar signos visuales que, de algún modo, representasen las imágenes mentales externalizadas por la voz remete a dominios primordiales cuyos enigmas y misterios desafían hasta hoy tanto la razón como las vislumbres inconscientes del hombre. Los inmensos intervalos entre el habla y las grafías que empezaron a representarla siembran alejamientos, lo que no significa, a mi ver, que entre ellas, habidos en cuenta los espacios de su discontinuidad, reinen vacíos absolutos, agujeros negros a los que la memoria nunca llega. Seguro que el silencio de los siglos asusta a las gentes y genera en ellas actitudes de indiferencia o, mejor dicho, formas en donde encubrir el miedo, el pánico proveniente de una ausencia velada cuya atmósfera se enrarece día a día, aunque los medios y los soportes comunicativos de la actualidad ofrezcan recursos que favorecen cada vez más la accesibilidad a gestos y resonancias considerados irrecuperables. No obstante, hay que reconocer que ante el silencio de las cosas ancestrales, el hombre siempre se hará preguntas y, aun no encontrando la respuesta avalada por los hechos, al menos tendrá a menudo la compañía fiel de la fantasía, pues, como afirma Buñuel:

"Cada respuesta dada a estas preguntas originará, a su vez, otras preguntas, progresivamente más numerosas. Nos hallaremos ante encrucijadas cada vez más complejas, que conduciran a otras encrucijadas, a laberintos 
fantásticos en los que habremos de elegir nuestro camino. Así, siguiendo causas aparentes, que no son, en realidad, sino una serie, una profusión ilimitada de casualidades, podríamos irnos remontando cada vez más lejos en el tiempo, vertiginosamente, sin pausa, a través de la Historia, a través de todas las civilizaciones, hasta los protozoarios originales." (1998: p. 201-202).

Me atrae, pues, la idea de que los pasajes más poéticos de los filmes de Buñuel cobijen, en su inconfundible estilo, la representación de imágenes que la fantasía utiliza para forjar esos laberintos y sus múltiplas encrucijadas. $\mathrm{O}$, dicho de otra manera, captan vestigios de esos dominios primordiales confinados por los misterios que calladamente esconde el vacío entre el habla y la escritura. Desde esa perspectiva, los momentos más significativos de la ferocidad inventiva del cineasta pueden ser entrevistos en esa suerte de manuscritos de las pulsiones que caracterizan una singular manera de escribir imaginerías en donde forcejean sin cesar componentes de la naturaleza y de la cultura, como forcejean en la remembranza de cualquier especie animal los incontables avatares de sus antepasados. Tales pasajes fílmicos son numerosos en el documental Las Hurdes (1932) - el burro aguijoneado, la cabra que se despeña, los gallos acéfalos, ${ }^{1}$ para dar algunos ejemplos -, pero la voracidad poética se exhibe todavía con extrema contundencia en escenas de Los olvidados (1950), Subida al Cielo (1952) o La Joven (1960). En estas películas, la representación en imágenes y sonido de los fenómenos naturales como la muerte, el sexo y la alimentación atraviesan las pupilas de los espectadores asumiendo configuraciones desconcertantes, aunque tal vez sean los fragmentos oníricos de sus principales obras los que reflejen, a través de la superposición de imágenes de la naturaleza e imágenes que pretenden

1. Hay que reconocer, sin embargo, que la naturalidad, en muchos casos, es forzada, como ocurre con la cabra: el plano nos deja ver sutilmente el humo del disparo que abate al animal y otro tanto ocurre con el burro, atado para que no puede esquivar el impiedoso ataque de los insectos. 
retratar el trabajo del inconsciente, con mayor carga semánticoexpresiva el vigor irracional de las pulsiones.

Tengo para mí que la utilización de animales salvajes o domesticados plasma una metáfora matricial mediante la cual el cineasta pone en escena la pugna entre los instintos y las normas elaboradas por la civilización. Los rituales de tal pugilato, aunque circundan cualquier situación humana, casi nunca se advierten, pues no se trata de incluir en ellos las grandes hecatombes de terremotos o erupciones volcánicas. ${ }^{2} \mathrm{Al}$ contrario, son fenómenos en que la sobrevivencia de los animales entra en juego. Acciones en las que el movimiento de los instintos parece estar precedido por algo tan silencioso como el deslizar de una araña o el combate de los escorpiones en el prólogo de la película L'âge d'or (1930), sin descartar que a veces el silencio ensancha sus enigmas, como ocurre en El Ángel Exterminador (1962), con la insólita presencia de un oso en la vivienda en que los burgueses están inexplicablemente encarcelados. El ruido del viento completa también el cuadro de lo invisible, vigente de manera irrebatible en Abismos de Pasión (1954) e impregnado de entresijos en L'âge d'or cuando la protagonista, en lugar de su imagen reflejada en el espejo, contempla, ensimismada y excitada, las nubes que se agitan atormentadas sobre la superficie cristalina.

2. Tal vez los tres filmes en que fenómenos naturales de menor proporción, las tormentas con sus rayos y truenos, aparecen para componer, con realismo no exento de misterio, el ambiente sonoro sean Robinson Crusoe (1952), La mort en ce jardin (1956) y La vía Láctea (1969) 


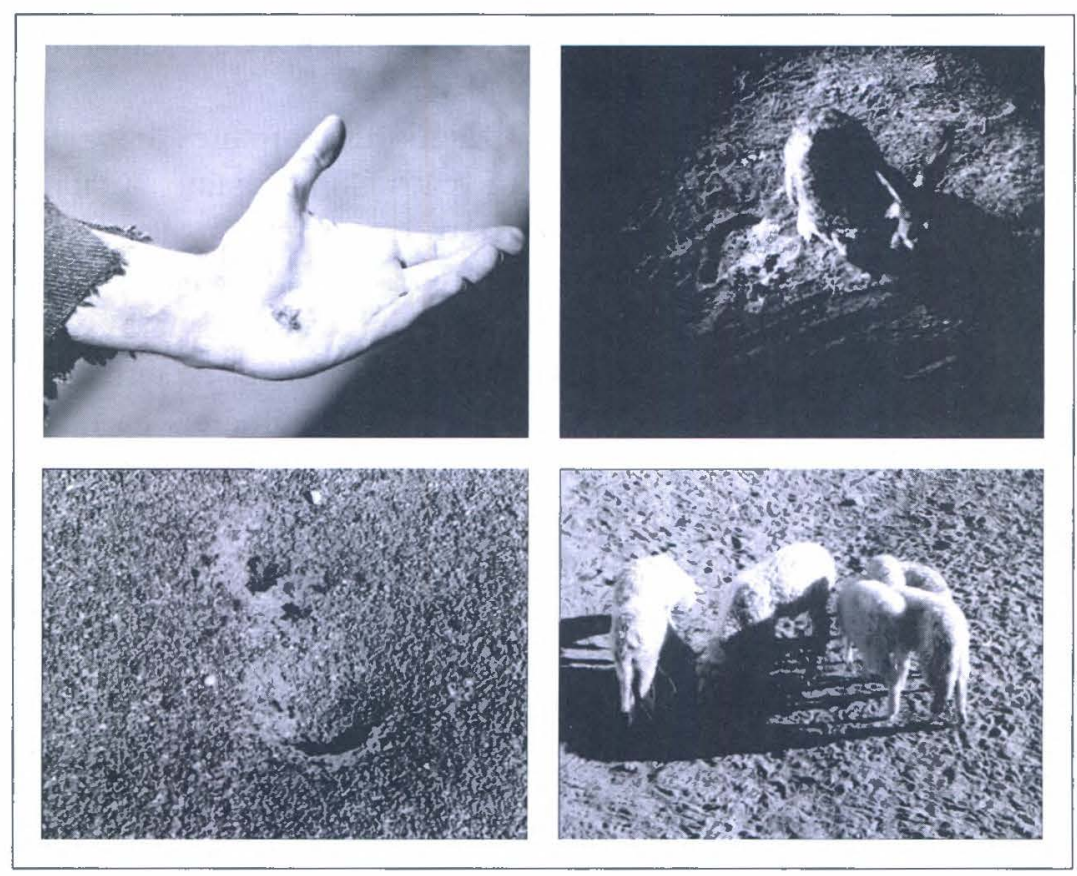

Figura 1. Fotogramas de Simón del Desierto

En general, el aparecimiento de los animales en Simón del Desierto (1965) se efectúa de forma muy singular. Surgen cuando menos se espera, pero con una cierta intermitencia, lo que me permite identificar la que parece ser su función más relevante. A su manifestación anteceden acciones o diálogos en los cuales la información se hace patente. O sea, la denotación de los actos y de las palabras de los personajes instaura un acto de comunicación que, aunque pueda ser irónico en ocasiones, es, grosso modo, transparente. Así, el grillo que el eremita tiene en su mano o las hormigas que gravitan sobre la boca del hormiguero son insectos bastante conocidos $y$, pese a eso, entran en escena cuando menos se espera, lo que causa extrañeza, un sentimiento de estupefacción que se asemeja mucho a lo que Freud denomina ominoso. ${ }^{3}$ Vale decir, por consiguiente,

3. En su famoso ensayo sobre lo ominoso (unheimlich), publicado en 1919, Freud reconoce que la inquietante extrañeza se relaciona al sentimiento de ser despo. 
que la irrupción de los insectos mencionados no sólo afecta la continuidad de las acciones, sino también que, al hacer emerger la connotación a través de los valores simbólicos, se cristaliza un atentado poético ${ }^{4}$ contra el contenido informativo de la denotación.

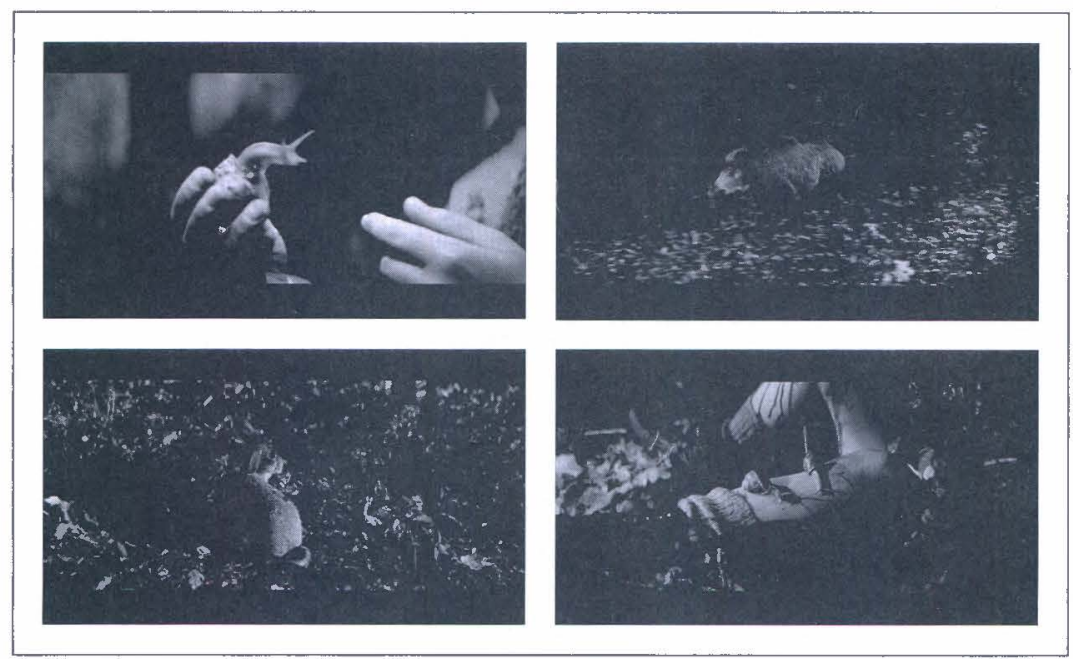

Figura 2. Fotogramas de Journal d'une femme de chambre (1964)

Ese proceso aflora con nitidez en una secuencia clave de Journal d'une femme de chambre. Trátase de las escenas en que se narra el paseo trágico de la niña en la floresta. Va vestida como si fuese Caperucita Roja y distraída con su propia inocencia. Busca caracoles y los que encuentra los va metiendo en un cesto de alambre. Come unas frutas silvestres y se encuentra con el cochero Joseph, a quien le ofrece frutillos. Se adentra en la bosque para, después de

jado de los ojos y, también, a la repetición. Ambas cosas son bastante significativas para estudiar algunos aspectos de los principales filmes de Buñuel, pero juzgo conveniente llamar la atención para los recursos repetitivos, pues ellos son una constante en el surgimiento intermitente de los animales en narraciones cinematográficas armadas por el director aragonés. (1992: p.215-251).

4. El concepto de lo poético como atentado se lo debemos a Barthes. 
algunas alternancias de su figura infantil y animales salvajes - un jabalí y un conejo -, aparecer inerte con las piernas llenas de sangre y dos caracoles caminando lentamente sobre uno de sus muslos. En ningún instante se evidencia el agente causador de ese desenlace.

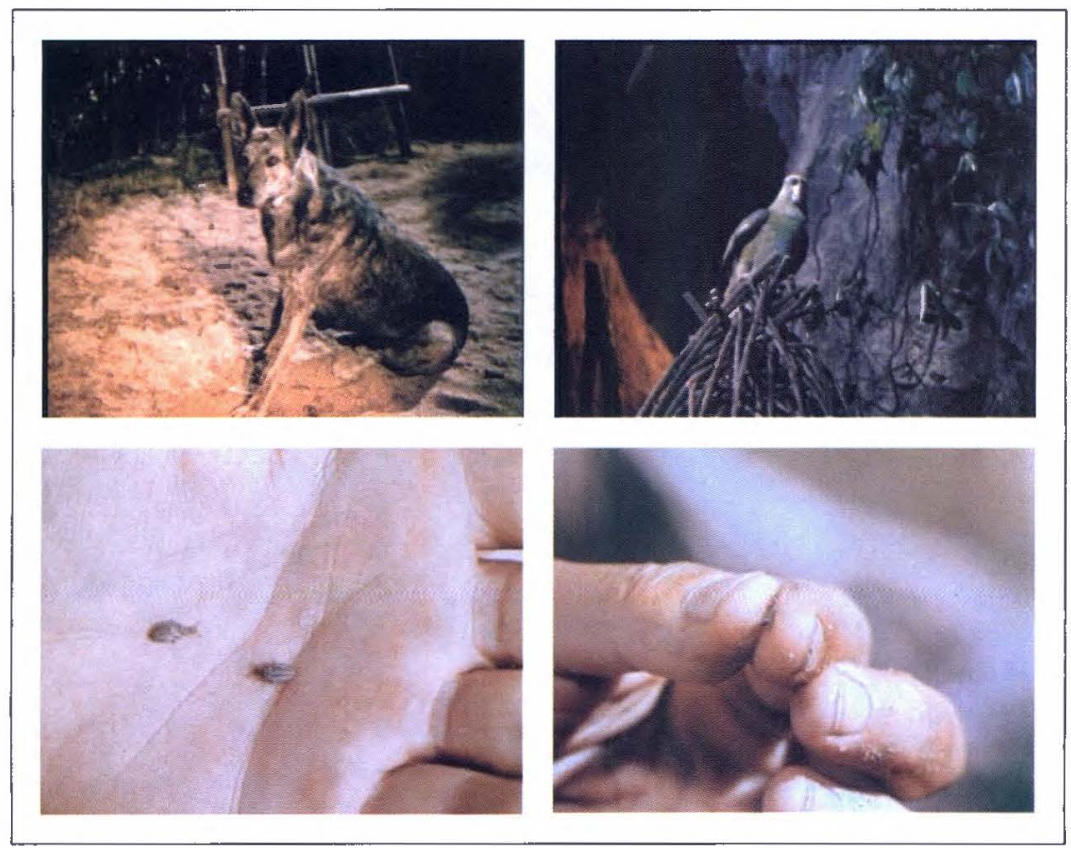

Figura 3. Fotogramas de Robinson Crusoe (1952)

En Robinson Crusoe, los animales, aunque no adquieran los significados enigmáticos que tienen en otros filmes, asumen un papel fundamental respecto a la soledad del hombre y a su libertad. Por un lado, el perro y el loro, son compañeros fieles, tanto en los momentos de comer como en los de dialogar. Por otro, las caracolillas y los insectos de la playa, travestida de "plaza pública", son camaradas a "quienes" el personaje busca para hablar. La soledad del náufrago en la isla tropical es imponente y la escena en que tal vez se represente con más intensidad ese estado es la que concierne al eco que, al devolverle las palabras, hace que, en tal situación existencial, 
la única "compañía" posible sea la resonancia de su propia voz. Pero Robinson, aun sintiendo en la soledad una inmensa falta, inventa la libertad utilizando para ello sus fantasías, la imaginación plasmada en diálogo con los animales.

A pesar de sus múltiplos matices, ese recurso, manipulado por Buñuel en casi todas sus películas, funciona como una especie de invariable a través de la cual se manifiestan los atisbos ideológicos del cineasta, principalmente los que se refieren a la libertad, a la imaginación, a la ciencia y a la información. A raíz de la pregnancia del recurso en cuestión, la puesta en fábula de los guiones, además de caracterizar un estilo inconfundible, abre la posibilidad de orientar la interpretación de la escritura fílmica según dos hipótesis: por un lado, la de que el misterio se expresa mediante el proceso de representar simultáneamente el anverso y el reverso de las cosas y, por otro, la de que es necesario escabullirse de la perversidad de la lógica informativa.

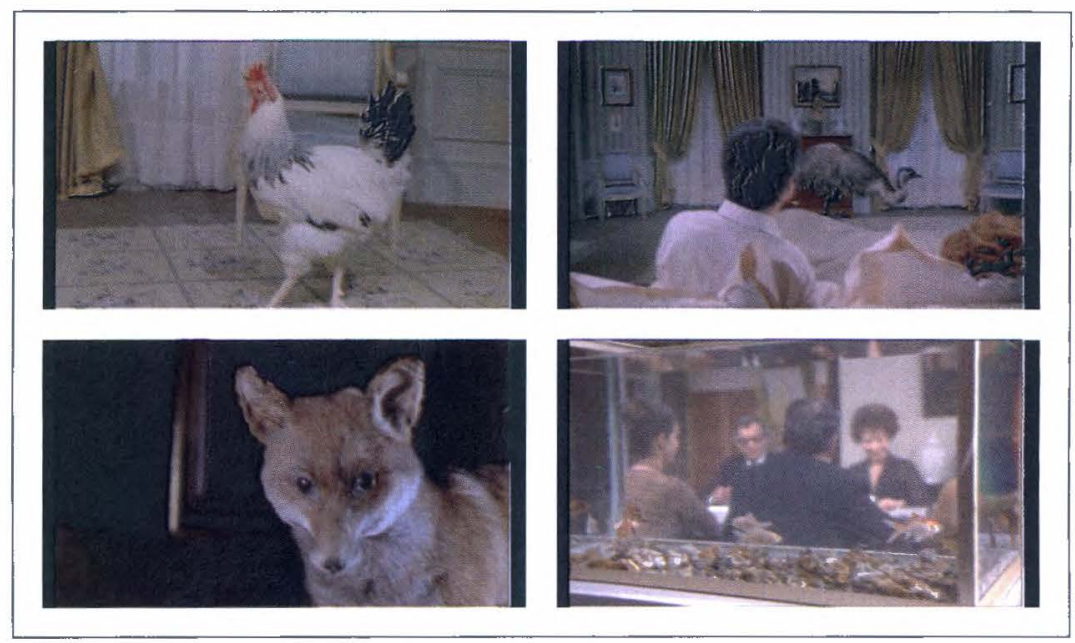

Figura 4. Fotogramas de Le fantôme de la liberté.

En lo que concierne a la primera hipótesis de lectura, la película Le fantôme de la liberté (1974) fornece claves muy precisas. 
En ella, el director aragonés bromea a lo serio, si se me permite decirlo así, con el constante ejercicio de escribir fílmicamente el instante en que la presencia y la ausencia se confunden y dan margen a esa ambigüedad poética con la que Buñuel construye la ironía. La presencia de lo cotidiano y de lo onírico - las dos caras de la medalla existencial - transforma la casa del matrimonio burgués que "había pedido una hija sin perderla" en una suerte de zoológico en que el gallo y el avestruz ${ }^{5}$ campean a sus anchas, exhibiendo los modales típicos de presas atrapadas en las trampas que les arman los fantasmas de la libertad. La zorra disecada de los espectros que persigue el ejército en los aislamientos sombríos de los bosques o, entonces, ese globo de cristal en que los peces - metáforas evidentes de los personajes - son confinados para satisfacer los caprichos ornamentales de los hombres.

Las simultaneidades de lo anverso y de lo reverso se ofrecen al espectador no sólo para plasmar poéticamente los hechizos de la contradicción, tan admirados por el cineasta, sino también para arremeter contra la rigidez de la ciencia y la intransigencia, sobre todo, de quienes piensan que el movedizo territorio de la denotación es la única verdad palpable. Además, la ambigüedad resultante de las configuraciones expresivas de sus principales películas es, también, el arma con la que el director acribilla, constantemente, la lógica de la información. A ese respeto, sin duda, el director de Viridiana es un visionario que anticipa los síntomas de algunos desvaríos de los tiempos venideros. En la actualidad, uno de esos desatinos vaticinados por Buñuel se deja ver con claridad en los conceptos que predominan en las cofradías hodiernas de comunicólogos, hipnotizados por una visión de mundo que parece priorizar lo informacional y la velocidad que los contenidos informativos conquistaron con los aportes de la tecnología. Tal vez entusiasmado con las conquistas de la ciencia, el animal humano de la sociedad contemporánea se embelesa con el

5. Esta secuencia adquiere significados más densos si se compara con la secuencia final del filme en la que el avestruz parece garabatear interrogaciones con la esbeltez de su cuello. 
canto de sirenas de la información y, sin amarrarse a ningún mástil, muere parcialmente a cada instante un poco atolondrado por el vertiginoso y perverso atropello de noticias que husmean lo nefasto o lo aciago. La rapidez con que los datos informativos se suceden parece destruir las particularidades discretas de los lenguajes y colocar en su lugar una continuidad falsa, un simulacro de entrelazamientos que nos encadena y no nos deja pensar.

Si con todo me detengo en el entremedio de lo vertiginoso y me pongo a pensar en serio algo sobre todo esto, he de convenir de pleno con lo que ya hace más de un cuarto de siglo anteveía Buñuel al decirnos:

"Las trompetas del Apocalipsis suenan a nuestras puertas desde hace unos años, y nosotros nos tapamos los oídos. Esta nueva Apocalipsis, como la antigua, corre al galope de cuatro jinetes: la superpoblación (el primero de todos, el jefe, que le enarbola el estandarte negro), la ciencia, la tecnología y la información. Todos los demás males que nos asaltan no son sino consecuencia de los anteriores. $Y$ no vacilo al situar a la información entre los funestos jinetes. El último guión sobre el que he trabajado, pero que nunca podré realizar, descansaba sobre una triple complicidad: ciencia, terrorismo, información. Esta última, presentada de ordinario como una conquista, como un beneficio, a veces incluso como un 'derecho', quizás sea en realidad el más pernicioso de nuestros jinetes, pues sigue de cerca a los tres y sólo se alimenta de sus ruinas. Si cayera abatido por una flecha, se produciría muy pronto un descanso en el ataque a que nos vemos sometidos.” (1998: p.297-298).

Pero aun así persiste en los seres pensantes la inquietud de la especie y, a pesar de no ladearse demasiado con la significación, sienten, como no podría dejar de ser, los efectos de haber perdido muchas cosas. Hoy, aun teniendo instrumentos para ahondar en capas todavía poco exploradas de nuestra memoria ancestral, las 
personas, en su mayoría, viven bastante enajenadas de todo cuanto signifique ir hacia el otro lado del entorno de hábitos consagrados y se tiene la sensación de que el animal humano contemporáneo usa diversos disfraces para esconder aún más las ciénagas de sus orígenes. Quizás en todo ese desconcierto hayan encontrado los teóricos de la comunicación motivos suficientes para dirigirse, en general, a un tipo de persona definida como un ser que parece tener repugnancia de lo que inexorablemente carga en sus entrañas. Mas las muchedumbres formadas por esas mismas personas ponen de relieve sus carencias esenciales, principalmente a través de la asiduidad con que se entregan a rituales que tienen estrecho parentesco con las cosas del mundo salvaje, sin que la salvajería, en el caso, denote algo negativo. Los aspectos más fútiles de esa actitud aparentemente irracional son tomados como paradigmas de comportamientos excluyentes y muchos son los que piensan que procedimientos de tal índole sólo tienen el significado de echar al basurero de los instintos más bajos pedazos de nuestro ser. Sería como si cada uno se inclinase a buscar fuera de sí lo que exige una búsqueda en los adentros, ya que cualquier ser humano, en tanto sujeto, sólo podrá aligerar el peso de sus pérdidas procurando en sí lo que no tiene solución en las afueras.

Pero en el ámbito de lo salvaje se hallan también, en sus capas más hondas, significaciones que, de algún modo, arraigan en dominios cercanos a lo ancestral. Porque, como afirma Julia Kristeva:

"Si es cierto que lo abyecto solicita y pulveriza simultáneamente al sujeto, se comprenderá que su máxima manifestación se produce cuando, cansado de sus vanas tentativas de reconocerse fuera de sí, el sujeto encuentra lo imposible en sí mismo: cuando encuentra que lo imposible es su ser mismo, al descubrir que él sólo es otro en lo abyecto. La abyección de sí sería la forma culminante de esta experiencia del sujeto a quien ha sido develado que todos sus objetos sólo se basan sobre la pérdida inaugural fundante de su propio ser." (2000: p.12). ${ }^{6}$

6. Al comparar la traducción argentina con el texto original me permití introducir unas pequeñas correcciones, necesarias para dejar más claras las ideas de Kristeva. 
Vale decir, por consiguiente, que aproximarse a lo primordial no es dar un salto en el vacío ya que el animal humano no arroja todo a la intemperie. Consciente o no, sabe guardar rasgos relevantes de lo que vive y de lo que hereda de la especie. Por mucho que se enajene, sus adentros siempre serán almacenes de asombros en donde se preservan "cosas" de toda índole. Trozos que, al desprenderse de la integridad que debemos de haber sido antes de la pérdida inaugural fundante golpean, cual astillas, los muros puestos por la existencia a las fuerzas del deseo. A todo instante, el hombre siente la pérdida inaugural, pues sobre el abismo que ella deja gravitan la grandiosidad de sus hazañas o la insignificancia de sus pequeñeces. Evidentemente no resultará fácil efectuar la aproximación a las simas que la pérdida inaugural deja, mas si se siguen las ideas de Kristeva necesario será reconocer que tales abismos están en nuestras entrañas y no en la geografía de las afueras. Además, si uno se amarra a las ambiguiedades forjadas por Buñuel en sus películas, seguro que la contradicción no será un escollo y tampoco será muralla capaz de retener las embestidas del deseo o de los instintos, en todo lo que esas dos fuerzas, desde siempre unidas, tienen de entrañable.

En esa visión de mundo, la escritura tal vez sea uno de los vestigios más fascinantes respecto a los efectos provocados por la pérdida de lo inaugural fundante. Entendida como expresión material de las imágenes mentales e instauradora de los actos comunicativos no se puede decir que haya nacido con los alfabetos. Antes del habla el hombre se comunicaba mediante gestos y éstos ya caracterizaban formas que, con el pasar de los tiempos, fueron caracterizando configuraciones distintivas a partir del instante en que cada una de ellas se vinculaba a significados específicos. Eso es lo que a través de ejemplos muy incitantes nos muestra Desmond Morris en el documental El lenguaje del cuerpo ${ }^{7}$ inspirado en su libro The Naked Ape (1967). Así, la sonrisa tendría su origen más remoto en el gesto

7. Aquí utilizo la edición española en DVD del documental hecho por el conocido zoólogo para la BBC. 
de miedo de los primates y en su insoslayable necesidad de encontrar en sí mismo las armas con que defenderse de todo lo que le produjese la sensación de peligro. El hombre, según Morris, fue lentamente transformando ese gesto hasta formar una expresión en la que cupieran sentidos distanciados del recelo, sentidos que transmitiesen la sensación de amistad y confianza. Y de tal mutación surge la sonrisa. Charles Darwin fue, a lo que se sabe, el primer científico en señalar que las emociones se han desarrollado, en su origen, para preparar las reacciones de los animales en situaciones de emergencia. ${ }^{8}$

Desde esa perspectiva, la "alfabetización" de la escritura de la imaginería, como la de cualquier tipo de escritura, conlleva un proceso de asociación. Vale decir que tanto las imágenes como las palabras adquieren existencia en el mundo de la expresividad a través de relaciones entre la materialidad presente de la escritura y configuraciones del pasado reguladas, tales relaciones, por procedimientos mnemónicos. Resulta, pues, evidente que en los transcursos de los rasgos, preservados consciente o inconscientemente por la memoria, para las grafías de la escritura se procesen diversas configuraciones del sentido, configuraciones esas que, en la vida social de los signos, formen significaciones variables. Eso queda claro si consideramos la posición de Darwin respecto a la sonrisa y las transformaciones que ese gesto sufre en su campo semántico para llegar al complejo significado de la risa.

Creo, aunque el asunto sea polémico, que en esa modalidad de escritura conseguida por Buñuel al combinar imágenes de animales y seres humanos se define una de las cataduras estilísticas más singulares del cineasta. Se sabe - y muchos son los estudiosos que coinciden en este punto - que el director aragonés no estaba interesado en crear personajes de ficción comprometidos con lo que sería una tentativa de representar la psicología de un individuo en particular. En sus películas, lo que predomina es el intento de expresar poéticamente el dato colectivo caracterizador del sustrato instintivo

8. Mucho se ha escrito sobre este asunto y aún asi el librito The Expression of the Emotions in Man and Animals (1934) no pierde el encanto de ser actual.

Significação $29 \cdot 22$ 
sobre el cual la humanidad y las clases sociales que la constituyen fundan sus emociones y actitudes. No es novedad afirmar que Buñuel centra su atención en la burguesía. Lo novedoso puede, en cierta medida, provenir de una práctica interpretativa de su escritura fundamentada en el principio de que lo que el cineasta parece representar es precisamente el anverso de lo que constituye uno de los paradigmas más fuertes del conservadurismo, de su discreto encanto y de los fantasmas de la libertad que deambulan en la oscuridad de sus recintos escondidos.

Desde ese punto de vista, en Viridiana (1961), por ejemplo, la abeja que se debate desesperadamente en el agua de una tina y que el personaje de Don Jaime, encarnado por Fernando Rey, salva con su aristocrático bastón, no significa únicamente el dilema individual en el que se va metiendo la protagonista del filme, sino también el contenido más amplio de una pulsión de muerte que acompaña con fidelidad al animal humano a partir del instante en que éste es lanzado al mar de la existencia. La abeja tiene como consuelo la vara pulida que la salva de su gran naufragio y que proyecta en la semántica de esta imaginería el significado metafórico de una esperanza. Pero, en Viridiana, la esperanza no tiene hueco en donde cobijarse ni encuentra motivo que la justifique. En esta película todo se orquesta según la ley implacable de los fenómenos naturales y, por eso, la modalidad de escritura a que ya me he referido se presenta a mis pupilas bajo la condición poética de un recurso expresivo destinado a evocar el misterio del gran naufragio a que es sometido el hombre desde su "primer suspiro". 


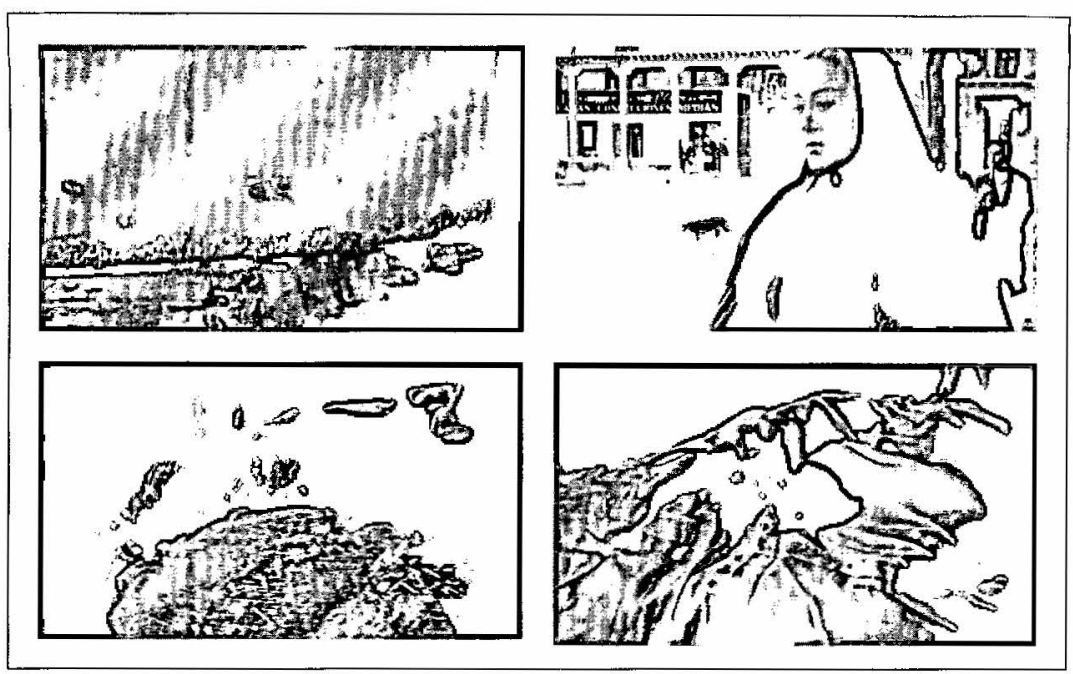

Figura 5: Fotogramas de Viridiana

La comparación entre Viridiana y la perra tiene, a su turno, un significado sutil que no se puede reducir al sentido habitual que la metáfora lexicalizada mujer-perra tiene en los contextos habituales de la cultura occidental. Leer ese fragmento fílmico a través del prisma de lo rutinero es caer en la trampa de la lógica dictada por el sentido común. Me parece que esa configuración expresiva tiene significados más transcendentes, mas comprometidos con el sentimiento ancestral de la soledad y del abandono, sustrato en que la significación podría hallar el sustrato mnemónico del que depende. Esa ley implacable de los fenómenos naturales en los que consciente o inconscientemente abreva nuestra memoria también se manifiesta en la pugna desigual, pero necesaria, que mantienen el gato y el ratón en la secuencia que retrata la irremediable y ansiada entrega de Ramona a los deseos carnales del Jorge representado por Francisco Rabal. En fin, esa relación de las imaginerías de Buñuel en que se combinan animales y seres humanos configura una modalidad de escritura para la cual las contradicciones no cuentan $\mathrm{y}$, por consiguiente, no son una barrera capaz de impedir o darle lustre melodramático a las emociones que arraigan en lo más hondo de la existencia humana. Sin embargo, vistas desde el ángulo de lo poético, 
esas imaginerías ponen de relieve un matiz poético propio de la ironía. Por un lado, se oponen a la lógica y, por otro, provocan en el espectador los atisbos de una risa que no llega nunca a la carcajada.

En los enmarañados de tal modalidad de escritura se enredan incongruencias, absurdos, exageraciones y juegos polisémicos cuyas técnicas y recursos recuerdan el trabajo de los sueños entendidos a la manera concebida por Freud. Lo que hay en todo eso de jocoso constituye, por tanto, una suerte de regresión, una forma de escapar de lo habitual para adentrarse en los sustratos del sentido de modo, en cierta medida, gratificante, pues de la confiabilidad de la sonrisa se pasa al regocijo irracional de la risa y en ese ritual inherente a la condición humana se infiltran, cuando menos se espera, los fantasmas de la libertad. Buñuel arremete contra los molinos de viento de la lógica o de la pretensa seriedad de la ciencia y su imaginería se introduce en el cerebro de los espectadores utilizando la lanza de la ironía, porque como señala Treguerres nuestro cerebro

"es un órgano esencialmente lógico: le gustan las cosas coherentes, simples, sencillas, significativas, ordenadas y con sentido. En procesos psíquicos tales como la percepción y la memoria nos ofrece buenas pruebas de ello (esa es seguramente la explicación de que el individuo excelente, desde el punto de vista intelectual, suele ser aquel capaz de ver lo mismo de otra forma distinta a como lo ve el común de la gente, o de organizar los mismos elementos de un modo diferente y novedoso: una manera de ver o relacionar opuesta, incluso, a la tendencia natural que seguiría su propio cerebro). Nuestro cerebro es también (si se me permite la broma, no exenta de cierta paradoja) un tipo muy serio y con escaso sentido del humor. Todas las situaciones risibles (y todos los chistes) tienen en común una serie de características absolutamente opuestas a aquéllas con las que el cerebro se siente cómodo: son absurdas, faltas de sentido, incongruentes, rebuscadas, desordenadas... El cerebro, enfrentado a ello, quiere entender y no puede; 
intenta ordenar, clasificar, simplificar, y por unos instantes cualquiera de tales actividades le resulta imposible, porque momentáneamente ha sido engañado por ese sutil juego de diferencias y semejanzas, que, por unos segundos, se ve impelido a reconocer como esenciales, aunque él sabe que no lo son, que son absurdas”. (2002: p.9)

Creo, pues, que el espacio que se confina entre el habla y su representación gráfica instituye un territorio en el que se dan encuentro los instintos comunes al animal y al hombre y lo que resta de ese encontronazo es precisamente lo que las huellas mnemónicas del animal humano preserva a través del acto de transformar el silencio de las cosas inmemorables en lenguaje. De ese esfuerzo en que se acurnulan experiencias seculares que se sobreponen al humus de los instintos surge, cuando nuestro cerebro se distrae o se descuida, el fantasma de la libertad, un espectro libertario que, en la filmografía de Buñuel, cabalga sobre los rocinantes de la poesía en sentido contrario al que siguen los jinetes del Apocalipsis.

\section{Bibliografia}

BUÑUEL, Luis. 1998. Mi último suspiro. Barcelona: Plaza \& Janés Editores.

DARWIN, Charles. 1934. The Expression of the Emotions in Man and Animals. Londres: Watts \& Co.

FREUD, Sigmund. 1992. Lo ominoso, in Obras Completas, volume XVII. Buenos Aires: Amorrortu editores.

KRISTEVA, Julia. 2000. Poderes de la Perversión. México: Siglo XXI.

TREGUERRES, Alfonso Fernández. 2002. De la risa, in El Catoblepas-Revista crítica del presente, número 8. 